\title{
Impact of Big Five Personality Traits on Entrepreneurial Intention of Engineering Undergraduates
}

\author{
W M I Udayanganie (Corresponding author) \\ Graduate School of Management, Management \& Science University \\ No 300, Galle Road, Colombo 3, Sri Lanka \\ E-mail: iresha.meegaawatta@gmail.com
}

Mazuki Jusoh

Graduate School of Management, Management \& Science University University Drive, Off Persiaran Olahraga, 40100 Shah Alam, Selangor, Malaysia

E-mail: keyjus@yahoo.com

Karuthan Chinna

Graduate School of Management, Management \& Science University

University Drive, Off Persiaran Olahraga, 40100 Shah Alam, Selangor, Malaysia

E-mail: karuthan@gmai

Received: July 24, 2019

doi:10.5296/rbm.v6i2.15147
Accepted: August 12, 2019

Published: August 20, 2019

URL: http://dx.doi.org/10.5296/rbm.v6i2.15147

\begin{abstract}
The purpose of this paper is to identify the influence of Big Five personality traits of extraversion, agreeableness, conscientiousness, emotional stability and openness to experience on entrepreneurial intention of engineering undergraduates. Entrepreneurship for engineers is not new to the world. Recent changes in the world and engineering present both challenges and opportunities to engineering education. Engineering education is changing to meet these challenges. A study was conducted with the sample of 202 final year undergraduates in engineering faculties in Sri Lanka. Exploratory Factor Analysis, Multiple Regression and Structural Equation Modeling were applied to analyze the relationships of these variables. The results demonstrate that entrepreneurial personality traits which relate significantly to entrepreneurial intention of undergraduates are characterized by high emotional stability and openness to experience. The findings are discussed and interpreted to provide important implications to practitioners and academics.
\end{abstract}

Keywords: Big Five traits, Entrepreneurial intention, Engineering undergraduates. 
1. Introduction

Entrepreneurship researchers have long examined the relationship between personality traits and entrepreneurial intention and development, successfully establishing the positive relationship between personality traits and entrepreneurial intention. In Sri Lanka local universities produce less than 5\% of Sri Lankan Entrepreneurs (Perera, 2012). So, there is a gap between the education and undergraduates' ambitions. The government of Sri Lanka needs to enhance intention of entrepreneurship among university graduates but the main challenge is that the education system and a larger percentage of graduates passing out from universities have a preference in searching for a salaried employment for themselves rather than exploring the opportunities for an entrepreneurial career. The low level of entrepreneurial inclination can be attributed to several factors like education, attitudes, social networks, behavior, culture and etc. Many researchers have conducted studies on entrepreneurial inclination using vast amount of different factors as mentioned earlier (eg: Linan \& Chen, 2009, Urban, 2006, Barney, 1991, Sesen, 2013 and etc). There are many studies based on personality which can impact on entrepreneurial intention (e.g., Brandstätter, 2003, Lüthje \& Franke, 2003, Zhao, Seibert, \& Lumpkin, 2009). However, they were unable to agree conclusively. For example, Zhao, Seibert, \& Lumpkin, (2009) concludes that all big five personality traits other than agreeableness are associated with entrepreneurial inclination. Lüthje \& Franke, (2003) concludes that personality traits have strong impact on attitude towards entrepreneurship and entrepreneurial inclination is linked with attitudes. Therefore, personality traits have indirect relation to entrepreneurial inclination. Especially in the Sri Lankan context, very few studies have been carried out regarding entrepreneurial inclination (eg: Thrikawala, 2011, Nishantha, 2008, Achchuthan \& Nimalathasan, 2012a, Dissanayake, 2013) and none of those studies examined personality factors.

Based on these empirical gaps, the current paper intends to examine the different of impact of high and low categories of Big Five personality traits act as a predictor of entrepreneurial inclination as a whole.

\section{Theoretical background and Research Model}

Historically, a long-standing assumption has been that entrepreneurs differ from other individuals with respect to personality (Baron, 2002, Zhao et al., 2009). Personality refers to one's relatively stable behavior patterns in response to various environmental factors and is often viewed in terms of traits (Daft, 2008). Researchers have examined thousands of traits over the years and have identified five general dimensions that can be used to describe an individual's personality (e.g. Golberg, 1992). These personality dimensions (the "Big Five") are extraversion, agreeableness, conscientiousness, emotional stability, and openness to experience. These factors represent a continuum, in that a person may score low, moderate, or high on each dimension.

\section{Big Five Personality Traits}

In 1982, Golberg developed the Big Five Model and again confirmed in 1990. This five factor model defines the individual's characteristics, patterns of thinking, feeling, behavior, and how they react to environmental changes in terms of five dimensions known as (1) 
extraversion, (2) agreeableness, (3) conscientiousness, (4) neuroticism, and (5) openness to experience. The five traits were varying from lower level to higher level among different individuals (Migliore, 2011). Big Five Model consist of several correlated but different traits. Jang, Livesley, Angleitner, Riemann, \& Vernon, (2002) concluded that each Big Five Model domain was made up of more than one common genetic factor and more than one common environmental factor. Among personality scholars there is a strong agreement that, on a broad level, the dimensions are relevant for specific behavioral domains. Extraversion and agreeableness denote about the domain of interpersonal behavior, whereas openness to experience is regarding individuals' intellectual life or idea-related endeavors. Conscientiousness is related to "engagement in task-related endeavors" (Ashton \& Lee, 2001, p. 346) and emotional stability relates to individuals' affective experiences or feelings (Ashton \& Lee, 2001).

According to Johan \& Srivastava (1999) extraversion is the energetic approach to social and material world and include traits such as sociability, activity, assertiveness, and positive emotionality. As mentioned by McCrae \& Costa (1987), extraverted people are social, assertive, active, bold, energetic, and adventurous. When relating with people, high extraverted are becoming prominent in their behaviour and expressiveness. On the other hand, low extraverted are seems to be quite (Costa \& McCrae, 1992). Furnham, Dissou, Sloan, \& Premuzic (2007) mentioned that "extraverts relate more easily to the outer world of people and things while Introverts' main interests are in the inner world of concepts and ideas". Individuals who were less in extraversion likes to be in the background and is viewed as less talkative, reserved and less action oriented (Migliore, 2011).

Agreeableness is the prosocial and communal orientation towards others with antagonism and include traits such as altruism, tender-mindedness, trust and modesty (Johan \& Srivastava ,1999). Characteristics of agreeableness are like altruistic, warm, generous, trusting, and cooperative (McCrae \& Costa, 1987; Costa \& McCrae, 1992). It is about the individuals' courteous, trusting, and cooperative demeanor (Goldberg, 1990). The people who are on agreeableness are appeared to be good-natured, considerate, and tolerant and in contrast to less agreeable individuals who seems to be manipulative, self-centered, and suspicious (Digman, 1990). People of high agreeableness consider about other's interests and they will try not to involve in conflicts and they are likely to cooperate with others and help others in order to maintain existing relationships (Sung \& Choi, 2009). Individuals recording high on agreeableness are also more adaptive while individuals scoring less in agreeableness are reluctant to involve with others (Migliore, 2011). Agreeable individuals, therefore, are more likely to focus on relational aspects (Costa, McCrae, \& Dye, 1991) and they tend to be overly compliant and thus may adjust their behavior in trying to accommodate others (Graziano \& Eisenberg, 1997).

Conscientiousness is the "socially prescribed impulse control that facilitate task and goal-directed behaviour, such as thinking before acting, delaying gratification, following norms and rules, and planning, organizing, and prioritizing task (Johan \& Srivastava ,1999). Features of conscientiousness are dependability, responsibility, dutifulness, deliberation, achievement orientation, and a concern for following established rules (McCrae \& Costa, 
1987). It is all about the scope of which individuals are purposeful, hardworking, persistent, and strive for achievement (Goldberg, 1990). Highly conscientious individuals tend to think carefully before acting and adhere closely to their moral obligations and perceived responsibility (Costa \& McCrae, 1992). In addition, highly conscientiousness people set clear goals and make huge effort to achieve those goals than the less conscientiousness people (Mount \& Barrick, 1995). The responsibility of conscientiousness (for example, responsible, dependable, and deliberate) may make individuals more likely to do the right thing, not only for themselves, but also for others (Moon, 2001).

Johan \& Srivastava (1999) denoted that "neuroticism contrast emotional stability and even-temperedness with negative emotionality, such as feeling anxious, nervous, sad and tense". Neuroticism depicts the extents to which people are anxious, defensive, insecure, and emotional (McCrae \& Costa, 1987). Individuals having high level of emotional stability are self-confident and relaxed in contrast to people with low emotional stability who are to be anxious, depressed, insecure, and fearful (Goldberg, 1990). In addition, people with less emotional stability avoid the situations which they feel they will fail; they lack the confidence about the social- and task-related risk which are involved in creative attempts (Raja \& Johns, 2004). Furthermore, emotionally established people have positive views about their task and other people and they are relaxed (Sung \& Choi, 2009). High score in neuroticism explains the emotional reactions to the negative feelings such as anger and anxiety where low score is explaining the emotional stability and calmness (Migliore, 2011).

Johan \& Srivastava (1999) describes "openness to experience as the breadth, depth, originality and complexity of individual's mental and experiential life". People who are open to experience are more like to have imagination, unconventionality, autonomy, creativity, and divergent thinking (McCrae \& Costa, 1987) and they are showing independence in judgments and autonomy (Woodman, Sawyer, \& Griffin, 1993). These things may guide open to experience people for finding new opportunities and unconventional ways to achieve organizational goals (De Hoogh, Hartog, \& Koopman, 2005). Individuals who has high marks on openness to experience have broad intellectual interest with a personal and non-confirming way of thinking when comparing to individuals who score low on openness to experience which prefer for familiarity and narrow intellectual focus (Migliore, 2011).

\section{Intention to entrepreneurship}

Since entrepreneurship occurs over time (Gartner et al., 1994), entrepreneurial intentions can be viewed as the first step in an evolving long-term process of organizational founding. It is also important to understand an individual's entrepreneurial intentions because it is a state of mind that directs the individual's attention, experience and action toward the goal of founding a business (Bird, 1988). Entrepreneurial intentions represent an individual's commitment to start a new business (Krueger, 1993). In addition, intentions towards a behavior have routinely been proven to be the best single predictor of that behavior (Fishbein \& Ajzen, 1975). Absent intention, action is unlikely. Hence, entrepreneurial intentions are crucial to understanding the overall process of entrepreneurship because entrepreneurial intentions serve as the key initial conduit for subsequent actions and events that affects the characteristics of the new organizations (Bird, 1988; 1992; Boyd \& Vozikis, 1994; Crant, 


\section{Macrothink}

1996; Jenkins \& Johnson, 1997; Katz \& Gartner, 1988; Krueger, 1993; 2000; Krueger \& Carsrud, 1993). Therefore, a model that focuses on entrepreneurial intentions offers an important framework to pursue a better understanding of the entrepreneurial processes (Krueger, 1993; 2000). Intentions play a key role in explaining human behaviors (Tubbs \& Ekegerg, 1991). Many social behaviors, such as creating a new business, are volitionally controlled and these behaviors have been found to be best predicted by intentions (Ajzen, 1991; 2005; Bagozzi et al., 1989). Similar to entrepreneurship, different understandings of entrepreneurial intentions have been observed. Katz and Gartner (1988) defined entrepreneurial intention in terms of looking for information and other resources to start up. Bird $(1988 ; 1992)$ defined that intention as a state of mind that emphasizes personal attention and experience to accomplish new venture creation. Focusing on cognitive representation, Tubbs and Ekeberg (1991) stated that an intention is a representation of actions planned to perform an entrepreneurial behavior. Other researchers, for example, Reynolds and Miller (1992) understood entrepreneurial intention as the personal commitment of the potential entrepreneur to start up. In the same way, Krueger (1993) and Krueger et al. (1995) argued that entrepreneurial intention is the commitment to performing entrepreneurial behavior.

Personality traits have been used as independent variables in the conceptual framework of the present study. These personality dimensions (the "Big Five") are extraversion, agreeableness, conscientiousness, emotional stability, and openness to experience. These factors represent a continuum, in that a person may score low, moderate, or high on each dimension. Considering the Big Five personality traits impact on entrepreneurial intention of Engineering undergraduates is been captured to develop the conceptual framework (Figure 01).

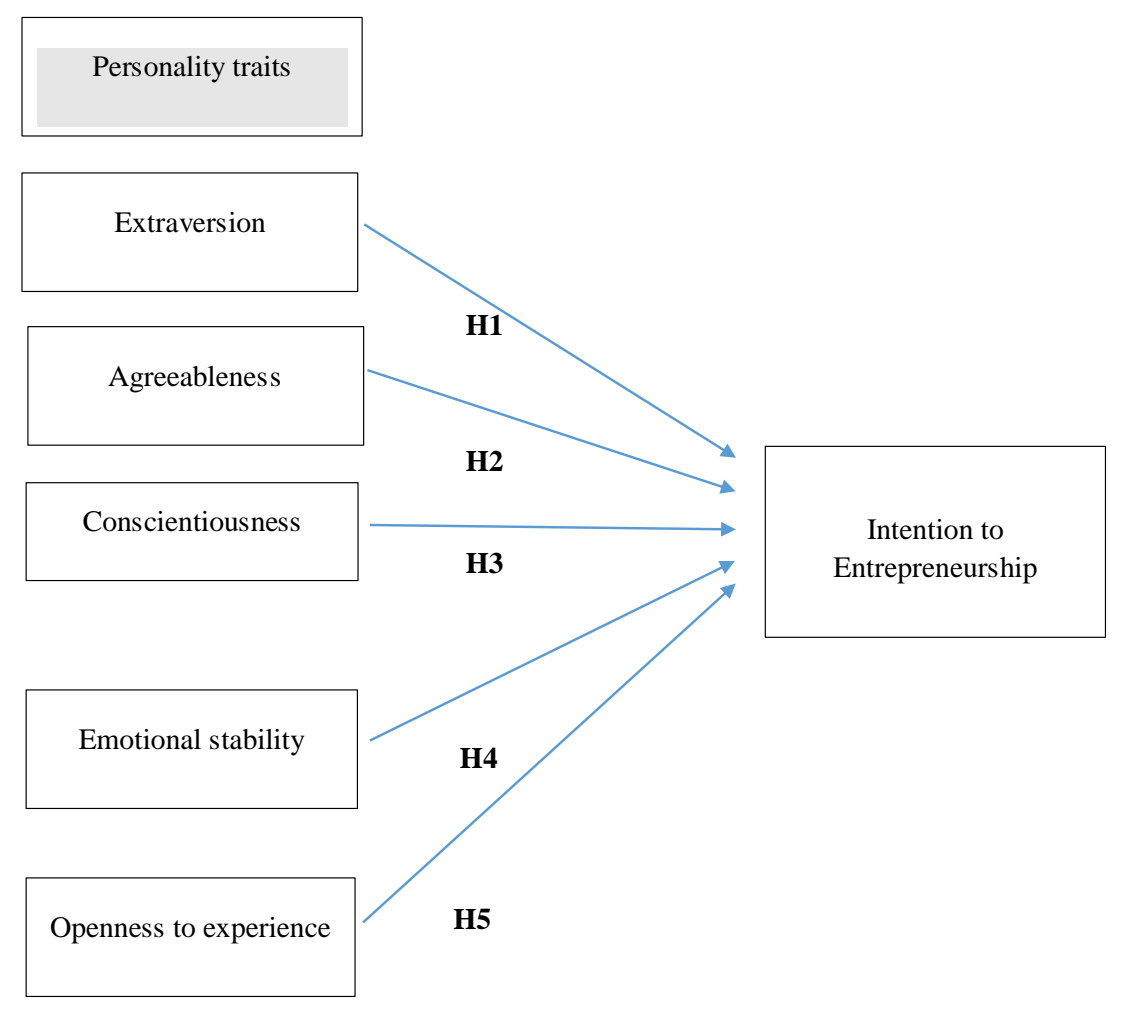

Figure 01 - Conceptual Framework 
Based on the conceptual framework, listed below are the postulated hypotheses:

H1: There is an association between the extraversion and an intention to entrepreneurial behaviour.

$\mathrm{H} 2$ : There is an association between the agreeableness and an intention to entrepreneurial behaviour.

H3: There is an association between the conscientiousness and an intention to entrepreneurial behaviour.

H4: There is an association between the emotional stability and an intention to entrepreneurial behaviour.

H5: There is an association between the openness to experience and an intention to entrepreneurial behaviour.

\section{Method}

Final year undergraduates of the selected three engineering faculties of Sri Lankan universities were selected as the study sample. The researcher selected a random sample of 300 final year undergraduates from the three engineering faculties who are enrolled in entrepreneurship-related modules. Out of the 300 students, 202 students responded to the survey questionnaire which made up a response rate of the study $67 \%$. A questionnaire was developed, expert reviewed, and piloted prior to the distribution among the undergraduates.

The Big Five dimensions were measured using Golberg's (1992) 35-item 'Mini Markers' scale. This scale consists of five 7-item bipolar subscales measuring the traits for each of the Big Five Factors (extraversion, agreeableness, conscientiousness, emotional stability, and openness to experience).

Bipolar satisfaction, importance, and likelihood scales can easily be replaced by unipolar scales that are more reliable and easier on the respondent (Kunz 2015). Consequently, this study utilized the unipolar Likert scale.

Entrepreneurial intention was measured using adopting an existing survey instrument that was already well-tested will enhance the validity of a study (Harris, 2013). Therefore, this study adopted the Entrepreneurial Intention Questionnaire (EIQ) of Linan and Chen, (2009)

\section{Results}

The standardized regression weights were used since they allow to compare directly the relative effect of each independent variable on the dependent variable (Crompton, H., Burke, D., Gregory, K. H., \& Gräbe, C. (2016). The statistical significance is based on the critical ratio (CR) of the regression estimate (Hair, 1998). 


\section{Ml Macrothink}

Table 1 presents the standardized regression estimates and the direct association between the variables.

Table 1. Results of the hypothesis testing

\begin{tabular}{|l|l|l|l|l|}
\hline Path & Estimate & S.E. & C.R. & P \\
\hline Ent.int. <--- Ex & .340 & .219 & 1.554 & .120 \\
\hline Ent.int. <--- Ag & .107 & .240 & .445 & .656 \\
\hline Ent.int. <--- Co & .015 & .150 & .099 & .921 \\
\hline Ent.int. <--- Em & .400 & .162 & 2.468 & .014 \\
\hline Ent.int. <--- Op & .557 & .237 & 2.352 & .019 \\
\hline
\end{tabular}

The results reveal that under personality factors, Emotional Stability and Openness to experience have significant positive associations with Intention to entrepreneurial behaviour of engineering undergraduates. The other three factors namely, Extraversion, Agreeableness and Conscientiousness have no significant positive association with Intention to entrepreneurial behaviour of engineering undergraduates.

\section{Discussion}

The findings indicate that personality has a significant influence on the entrepreneurial inclination among undergraduates. However, based on CT Liang's (2015) study, it was found that significant positive effect of Conscientiousness and Openness to experience of technological undergraduates in Taiwan. Another study on the impact of personality traits on entrepreneurial capacity of undergraduates by C.R. Dennis (2016) showed a higher relationship of these factors.

Entrepreneurship courses carried out by universities should be designed in such a way that the personality of students is being considered as to improve the likelihood of creating business ventures in future. When selecting undergraduates for the entrepreneurial study programs, personality of students can be ascertained to help the engineering faculties achieve the objective of creating entrepreneurs.

On the other hand, universities can create more stimulating activities on the students with right personality to become an entrepreneur and also to develop their personality to be more entrepreneurially inclined.

Not only for the university students also can identify whether they can take the advantage of following entrepreneurship modules with regard to their personality. So what is important is to make programs which improve the personality of undergraduates, who has entrepreneurial personality to take the initiatives of venture creation. Organize and participate for idea generation workshops, through workgroups, brainstorming, etc. for the development of innovative projects, so that they may be subsequently analyzed and the results discussed. Students who has entrepreneurial personality can highlight by participating and evaluating of workshops. 


\section{Conclusion}

This paper gives a special attention on the relationship of Big Five personality traits and entrepreneurial intention. Findings in this study provide useful insights on improving entrepreneurship capacity among final year Engineering undergraduates. It was found those high in emotional stability and openness to experience are tend to have higher entrepreneurial intention. Based on the findings, the paper offers valuable guidelines and insight for those academics, practitioners and government officials who may want to review the effectiveness of current systems of the country and make changes in order to foster the entrepreneurial personality of undergraduates. This is particularly important in the context of a developing country such as Sri Lanka seeking to create an entrepreneurial culture for further socio-economic growth and development.

\section{References}

Ajzen, I. (1991). The theory of planned behavior. Organizational Behavior and Human Decision Processes, 50(2), 179-211, 1991.

Ashton, M. C., \& Lee, K. (2001). A theoretical basis for the major dimensions of personality. European Journal of Personality, Vol 15

Baron, R.A., \& Markman, G. D. (1999). Cognitive mechanisms: Potential differences between entrepreneurs and non-entrepreneurs. In P. D. Reynolds, W.D. Bygrave, et al. (Eds.), Frontiers of entrepreneurship research. Wellesley, MA: Babson College.

Bird, B. (1988). Implementing entrepreneurial ideas: The case of intentions. Academy of Management Review, 13(3), 442-454.

Brandstätter, H. (2011). Personality aspects of entrepreneurship: A look at five meta-analyses. Personality and individual differences, 51(3), 222-230.

Costa Jr, P. T., McCrae, R. R., \& Dye, D. A. (1991). Facet scales for agreeableness and conscientiousness: A revision of the NEO Personality Inventory. Personality and individual Differences, 12(9), 887-898.

Daft L., (2005) The Leadership Experience, 3rd Edition.

De Hoogh, A. H. B., den Hartog, D. N., \& Koopman, P. L. (2005). Linking the Five-Factors of personality to charismatic and transactional leadership; Perceived dynamic work environment as a moderator. Journal of Organizational Behavior, 26, 839-865.

Denis, C. R., Ariyarathne, C., \& Perera, C. (2016, December). A Study on the Impact of Personality Traits on Entrepreneurial Capacity of Undergraduates of Faculty of Management Studies of Sabaragamuwa University of Sri Lanka. In University of Sri Jayewardenepura, Sri Lanka, 13th International Conference on Business Management (ICBM).

Digman, J. M. (1990). Personality structure: Emergence of the five-factor model. Annual Review of Psychology, 41, 417-440

Gartner, W. B., \& Vesper, K. H. (1994). Experiments in Entrepreneurship Education: Successes and Failures. Journal of Business Venturing, 9, 179-187. 
Katz, J., \& Gartner, W. B. (1988). Properties of emerging organizations. Academy of management review, 13(3), 429-441.

Goldberg, L. R. (1992). The development of markers for the Big-Five factor structure. Psychological assessment, 4(1), 26.

Graziano, W. G., \& Eisenberg, N. (1997). Agreeableness: A dimension of personality. In Handbook of personality psychology (pp. 795-824). New York: Academic Press.

Hair Jr., J. F. (1998). Multivariate Data Analysis with Readings. Englewood Cliffs, NJ: Prentice-Hall.

Harris, D. M. H. (2013). Intentions of Self-Employment in the Real Estate Industry: Applying Ajzen's Theory of Planned Behaviour. A Dissertation Presented in Partial Fulfilment of the Requirements for the Degree Doctor of Philosophy, Capella University.

Hisrich, R.D. (2000). Entrepreneurial dimensions: The relationship of individual, venture, and environmental factors to success. Entrepreneurship Theory and Practice, 24(4), 79-90.

Jang, K. L., McCrae, R. R., Angleitner, A., Riemann, R., \& Livesley, W. J. (1998). Heritability of facet-level traits in a cross-cultural twin sample: support for a hierarchical model of personality. Journal of personality and social psychology, 74(6), 1556.

John, O. P., \& Srivastava, S. (1999). The Big Five trait taxonomy: History, measurement, and theoretical perspectives. Handbook of personality: Theory and research, 2(1999), 102-138.

Ashvini, K. S. (2011). Entrepreneurship Benefits Economy More than Just Generating Jobs. Retrieved at http://aks-blog.com. 2011

Krueger, N. F. (1993). The impact of prior entrepreneurial exposure on perceptions of new venture feasibility and desirability. Entrepreneurship: Theory \& Practice, 18(1), 5-21.

Krueger Jr, N. F., Reilly, M. D., \& Carsrud, A. L. (2000). Competing models of entrepreneurial intentions. Journal of business venturing, 15(5-6), 411-432.

Kunz, T. (2015). Rating scales in Web surveys. A test of new drag-and-drop rating procedures. Technische Universität, Darmstadt [Ph.D. Thesis].

Kuratko, D. (1995). Entrepreneurship in international encyclo- pedia of business and management. London, UK: International Thomson Press.

Migliore, L. A. (2011). Relation between big five personality traits and Hofstede's cultural dimensions: Samples from the USA and India. Cross Cultural Management: An International Journal, 18(1), 38-54.

Liang, C. T., Chia, T. L., \& Liang, C. (2015). Effect of personality differences in shaping entrepreneurial intention. International Journal of Business and Social Science, 6(4.1), 166-176. 
Liñán, F., \& Chen, Y. (2009). Development and cross-cultural application of a specific instrument to measure entrepreneurial intentions. Entrepreneurship Theory \& Practice, 5, 593-617.

Liñán, F., \& Chen, Y.-W. (2006), Testing the Entrepreneurial Intention Model on a Two-Country Sample.

McCrae, R. R., \& Costa, P. T. (1987). Validation of the five-factor model of personality across instruments and observers. Journal of personality and social psychology, 52(1), 81.

Mount, M. K., \& Barrick, M. R. (1995). The Big Five personality dimensions: Implications for research and practice in human resources management. In K. M. Rowland \& G. Ferris (Eds.), Research in personnel and human resources management (Vol. 13, pp. 153-200)

Perera, K., Jayarathna, L., \& Gunarathna, R. R. P. K. (2011). The Entrepreneurial Intention of Undergraduates in Sri Lankan Universities. Kelaniya, University of Sri Lanka Kelaniya.

Sung, S. Y., \& Choi, J. N. (2009). Do big five personality factors affect individual creativity? The moderating role of extrinsic motivation. Social Behavior and Personality: an international journal, 37(7), 941-956.

Thrikawala, S. (2011). The determinants of entrepreneurial intention among academics in Sri Lanka. International Proceedings of Economics Development \& Research, 4, p454-468.

Tubbs, M. E., \& Ekeberg, S. E. (1991). The role of intentions in work motivation: Implications for goal-setting theory and research. Academy of Management Review, 16(1), 180-199.

Woodman, R. W., Sawyer, J. E., \& Griffin, R. W. (1993). Toward a theory of organizational creativity. The Academy of Management Review, 18(2), 293-321.

\section{Copyright Disclaimer}

Copyright reserved by the author(s).

This article is an open-access article distributed under the terms and conditions of the Creative Commons Attribution license (http://creativecommons.org/licenses/by/3.0/). 